\title{
Taming Pandemics in International Relations
}

\section{Why Do States Cooperate in Transboundary Crises? An Applied History Perspective}

\author{
Beatrice de Graaf \\ Faculty of Humanities and Geesteswetenschappen, Universiteit Utrecht, \\ Utrecht, The Netherlands \\ b.a.degraaf@uu.nl
}

Received September 2020 | Accepted November 2020 |

Published online December 4, 2020

\begin{abstract}
This article introduces three historical situations where governments, or more accurately, specific leaders in office, shaped the international context in dealing with a transboundary crisis - and were in turn crucially affected in their reign by this crisis. The question at stake is: under what conditions did leaders (and their governments) engage in international cooperation to deal with the transboundary crisis at hand, and how did this cooperation impact the development of the crisis? An informed argument is made for combining crisis management research — in particular a model operationalizing conditions for transboundary cooperation - with an applied history perspective to shed light on the current obstacles to international cooperation in Covid-19 times.
\end{abstract}

\section{Keywords}

transboundary/transnational cooperation - international relations - pandemics in history - Napoleon - Concert of Europe - Spanish Flu - Covid-19 


\section{Napoleon and Merkel}

International relations shape pandemics and pandemics shape international relations. But what does it mean to see the Covid-19 pandemic as a transboundary crisis? Coming from the discipline of political history and international relations, it is remarkable to notice that this crisis is being discussed in statistical terms mostly, not just in the Netherlands, but overall. We discuss it in numbers; we talk about the reproduction number $(\mathrm{R})$, case fertility rates (CFR S), superspreaders, and curves. Mathematical discussions on aerosols and epidemiological graphs are our communicative currency. But the crisis is as much a social, cultural, and political one as a statistical one, and it is even more an international political one-since a pandemic is defined as "an epidemic occurring worldwide, or over a very wide area, crossing international boundaries and usually affecting a large number of people."1

According to Arjen Boin, a transboundary crisis can be defined as one that:

effortlessly exceeds geographical, policy, cultural, public-private and legal boundaries that normally enable public managers to classify, contain and manage a crisis. It escalates rapidly and mutates constantly, creating confusion about causes and possible consequences. It ends up on many administrative tables, but it is not obvious which of those tables is or should be "in the lead." These features make a fast and adequate response difficult, to say the least. ${ }^{2}$

Such transboundary crises exceed more than just territorial borders, they impact multiple domains and transcend all kinds of policy distinctions. We can point to previous pandemics, such as the SARS virus crisis in 2002, which spread from China to thirty-seven countries; the financial crisis of 2008, which collapsed the US economy and heavily affected economies in Europe; the eruption of a volcano on Iceland that incapacitated air traffic across the world; or the 2015 migration crisis, when the migrant flow from Syria via Turkey caused political and humanitarian crises across Europe. In such situations, traditional crisis management repertoires-oftentimes geared toward managing regionally constrained or national crises-are insufficient in the face of the transboundary challenges. ${ }^{3}$ That is problematic, given the fact the people generally

1 J.M. Last, ed., A Dictionary of Epidemiology, 4th ed. (New York: Oxford University Press, 2001).

2 A. Boin, "Transboundary Crisis Management: Why We Are Unprepared and the Road Ahead." Journal of Contingencies and Crisis Management 27 (1) (2019), 94-99, 94.

3 Boin, "Transboundary Crisis Management"; D. Blondin and A. Boin, "Cooperation in the Face 
rely on their states to solve national security crises and work with other states to deal with transboundary threats if they cannot do it on their own. Only rarely do, for example, non-state actors participate in such crisis response activities (during the migration crisis of 2015 NGO s jumped in to alleviate the humanitarian crisis among refugees, at sea and in refugee camps). ${ }^{4}$

To underline the innate international and political character of a pandemic both in its hot crisis stage and in its cold impact stage, ${ }^{5}$ this article introduces three historical situations, where governments, or specific leaders in office, shaped the international context in dealing with a transboundary crisis-and were in turn crucially affected in their reign by this crisis. The question at stake is: under what conditions did leaders (and their governments) engage in international cooperation to deal with the transboundary crisis at hand, and how did this cooperation impact the development of the crisis? Before the research question is further laid out and an informed argument is made for combining crisis management research with an applied history perspective, we start with two leaders who put a distinct stamp on the transboundary crisis that erupted during their reign.

\subsection{Napoleon in 1799}

Napoleon stands out because his invasions and wars of occupation shaped international relations between 1798 and 1815 and briefly transformed the world into a stage of unipolar power preponderance. ${ }^{6}$ Yet, his imperial overstretch ushered in new invincible enemies: infectious diseases-strangely enough a factor in Napoleon's downfall that has been quite overlooked in historiography. ${ }^{7}$

of Transboundary Crisis: A Framework for Analysis." Perspectives on Public Management and Governance 3 (3) (2020), 197-209, 199.

4 And even there, NGO s cannot replace coordinated international approaches to crisis management. See V. Nadal, "Why NGo s are Ineffective in Solving the Migrant Crisis: The Libyan Slave Trade Example." Global Affairs Strategic Studies, 13 March 2018, https:/www.unav.edu/web/ global-affairs/detalle/-/blogs/why-ngos-are-ineffective-in-solving-the-migrant-crisis-the-lib yan-slave-trade-example (accessed 31 August 2020).

5 W.T. Coombs, Ongoing Crisis Communication: Planning, Managing and Responding, and ed. (Los Angeles: Sage Publications, 2007).

6 D.A. Bell, The First Total War: Napoleon's Europe and the Birth of Warfare as We Know It (New York: Mariner Books, 2008); Charles Esdaile, Napoleon's Wars: An International History, 18031815 (London: Penguin Books, 2008).

7 Older literature mentioned the impact of diseases, but it has hardly survived in memory and public literature as one of the key factors that explained the Grande Armee's defeat: F. Cartwright, and M.D. Biddiss, Disease and History (New York: Crowell, 1972), 105; D.G. Chandler, The Campaigns of Napoleon (New York: MacMillan, 1966), 756. 


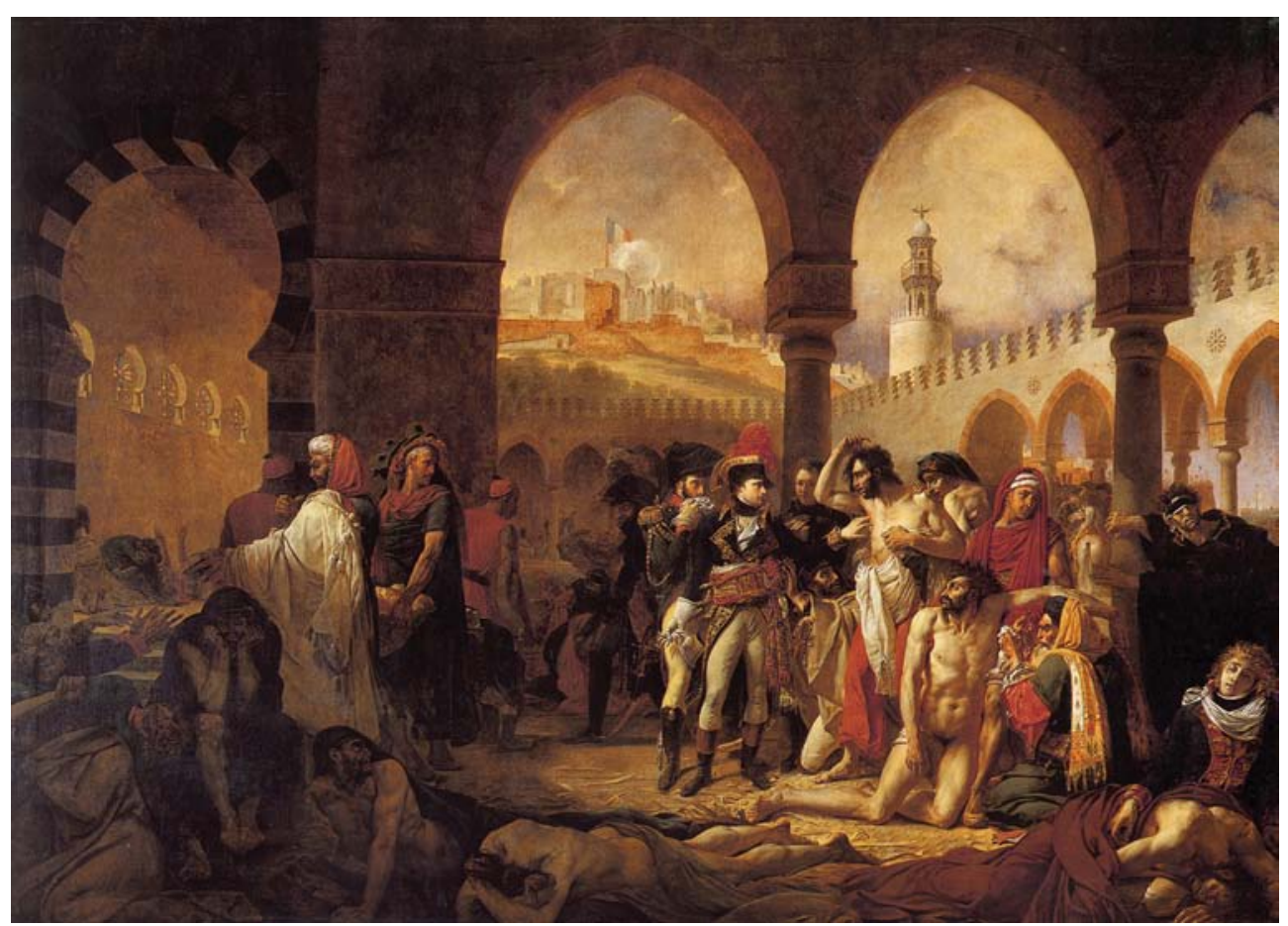

FIG URE 1 Bonaparte Visits the Plague Stricken in Jaffa (French: Bonaparte visitant les pestiférés de Jaffa) is an 1804 painting commissioned by Napoleon Bonaparte by Antoine-Jean Gros to portray an event during the Egyptian Campaign (1798-1799).

SOURCE: ANTOINE-JEAN GROS, BONAPARTE VISITANT LES PESTIFÉRÉS DE JAFFA, 1804. LOUVRE

After having successfully subdued all of Europe, Napoleon decided to push into the Levant and on toward India. He crushed Ottoman and Mamluk forces in Egypt in 1798 and continued to invade southern Syria. In early March 1799, he took the harbor city of Jaffa. The violent sacking of Jaffa was rapidly followed by an outbreak of bubonic plague, which decimated the army. With his victory, Napoleon brought home trophies from Egypt while inflicting disaster on his swarming armies. ${ }^{8}$ The painting above (see Figure 1) dates from 1804 and tries to depict Napoleon as a king of yore, administering the royal "touch" to a dying soldier during the Jaffa campaign of $1798-1799 .{ }^{9}$ In reality, Napoleon ordered

8 See P. Strathern, Napoleon in Egypt: The Greatest Glory (London: Jonathan Cape, Random House, 2007); R.K.D. Peterson, "Insects, Disease, and Military History: The Napoleonic campaigns and historical perception." American Entomologist 41 (3) (1995), 147-160.

9 D.G. Grigsby, "Gross' Bonaparte Visiting the Plague Victims of Jaffa, 1804." In Extremities: Painting Empire in Post-Revolutionary France, ed. D.G. Grigsby (New Haven, CT: Yale University Press, 2002), 65-103. 
Armenian priests to take care of his dying soldiers and fled home as quickly as he could — with the plague killing his remaining troops. A similar fate befell the troops commanded by his brother-in-law, General Victor Emmanuel le Clerc, whose armies went to Haiti and St. Domingue to suppress a slave rebellion, but whose troops were ravaged by the yellow fever rampant in the quagmires and swamps around Port-au-Prince. The French troops had no immunity to the disease, and their doctors were medically ignorant of ways to successfully treat such unknown infectious diseases. More than fifty thousand French soldiers perished. ${ }^{10}$

Napoleon had met his match in diseases he could not conquer and abandoned all ideas about expanding the empire further into North America. Yet, in 1812, Napoleon again transgressed geographical and biological borders. He pushed the Grand Armée too deep into the Russian winter, where 500,000 troops were obliterated by cold, cholera, diphtheria, typhus, and typhoid fever. It seems that Napoleon lost "only" 41,000 troops in combat and over 200,000 because of microbiological enemies alone."1

In sum, in trying to enforce and expand a unipolar world system, Napoleon's Grande Armée turned itself into a causative agent that enabled the emergence of infectious diseases among its own forces and along its march - thereby contributing to the corrosion of his empire.

\section{$1.2 \quad$ Angela Merkel}

To underline the nexus of international relations and pandemics as a transboundary crisis, a second example strikes a totally opposite tone. Jumping two hundred years into the future, for Chancellor Angela Merkel of Germany, pandemics are an overriding argument to work toward more international cooperation and overcome unilateral courses of action.

In June 2020, amid a searing Covid-19 crisis, Chancellor Angela Merkel and French President Emmanuel Macron, Napoleon's successor, announced a new Franco-German plan intended to jointly reform and reinforce the EU against the strong currents of populism and the shock of the UK's departure from the EU. The plan was unveiled as an unheard of economic recovery proposal for a corona-ravaged Europe. The EU commission, the two leaders announced, would borrow 75 o billion Euros from the financial market to fund the venture, and the money would be used both as gifts and as loans to those countries, markets, and companies in Europe that needed them the most. ${ }^{12}$

\footnotetext{
10 See Peterson, "Insects, Disease, and Military History."

11 R.F. Delderfield, The Retreat from Moscow (New York: Atheneum, 1967), 279.

12 Reuters, "Merkel, Macron Hope for EU Summit Deal on Budget, Recovery Fund." Reuters,
} 
Where Merkel had always been reluctant about a mutualization of EU debt, she now leaped forward to embrace a proper EU virus fund. In her words, "Germany only prospers when the EU prospers." According to the German chancellor, Europe needed reconstruction now or it would not survive. ${ }^{13}$ Indeed, the Covid-19 crisis has acted as a trigger for a new stage in the EU's economic and financial integration and recovery. With its 750 billion Euro recovery fund, the European Commission — propelled by Germany and France—is strengthening its internal market and at the same time reshaping the fragmented global world order vis-à-vis a dwindling leadership role for the United States. ${ }^{14}$

The two historical cases presented above reveal the nexus between pandemics and international relations. As stated above, pandemics are by their nature transboundary crises. They are rare and unique. Yet, the world has seen such crises before. They have been the product of wars and international developments (in trade, in the wake of natural disasters, or after migration streams). But pandemics have themselves equally been crucial causative agents in the shaping of international relations over the last two centuries, where globalization and internationalization have taken flight. In order to highlight the interaction between international relations and pandemics and the way governments and leaders have handled these in the past, this article aims to lay out some ways we can profit from adopting an "applied history" perspective.

\section{An Applied History Perspective on Transboundary Crises}

"Applied history," to follow Christopher Colvin and Paul Winfree, is historical research that does not have as its end goal the collection of evidence for historical analysis or to verify theories. Rather it points to research that identifies deep tendencies that help explain current problems and helps policy makers and citizens alike in pointing to the usefulness and limitations of universal theories. ${ }^{15}$ Applied historians, such as Margaret MacMillan, believe that history "aids in

29 June 2020, https://www.reuters.com/article/us-germany-france/merkel-macron-hope -for-eu-summit-deal-on-budget-recovery-fund-idUSKBN24O2 $\mathrm{G}_{3}$ (accessed 31 August 2020).

13 J. Hill, "Coronavirus: Why Merkel May Help Fund Europe's Recovery Plan." вBC, 27 May 2020, https://www.bbc.com/news/world-europe-52807748 (accessed 31 August 2020).

14 S. Fleming, M. Khan, and J. Brunsden, "EU Leaders Strike Deal on $€_{75}$ obn Recovery Fund after Marathon Summit," Financial Times, 21 July 2020, https://www.ft.com/content/ 713be467-ed19-4663-95ff-66f775af55cc (accessed 31 August 2020).

15 See C.L. Colvin and P. Winfree, "Applied History, Applied Economics, and Economic History." Journal of Applied History 1 (1-2) (2019), 28-41. 
formulating questions, and without good questions it is difficult to begin to think in a coherent way." ${ }^{\prime 6}$

These insights can be operated in four directions, if applied to the current Covid-19 crisis. First, historical cases can serve as an instrument of nuance, of contextualization. Much of what we are going through today, happened before. We are not the first ones looking for guidance, direction, and solutions. Each crisis emerged within its own set of unique, historical circumstances, yet at the same time revealed larger patterns of more, or less, successful crisis management in the ways governments and societies responded to that crisis. Second, history can help us craft concrete, sense-making explanations. Where did we come from? Covid-19 seemed to happen overnight, but it did not. It was a long time in the making, both as the product of increasing incursions of human civilization into natural life (deforestation, bushmeat, wet markets) and as the result of increasing global interactions (the rapid dissemination of the virus via tourism, trade, and global traffic). Third, history provides us with not only positive lessons but also failure paths: it shows us how solutions with the best intentions did, in fact, make matters worse. Instead of only looking into the past for positive evidence, and for confirmation bias, history also has all kinds of failures in store for those who want to learn how not to cope with crises. Finally, history is our citizen's resource, it points to citizen resilience through time and shows us that leaders as well as their experts, advisers, scientists, along with ordinary citizens with their bottom-up knowledge provided the resources that helped mitigate the crisis. ${ }^{17}$

If we adopt this applied history perspective, the research question can be formulated as such: if a pandemic is by nature a transboundary crisis, and not just a local or national one, how did the conditions that stimulate cooperation play out in historical situations where the international community of states was challenged not just to find the "cure for the disease" (something that was not possible in the pre-World War II period because of the lack of knowledge regarding bacteria and viruses), but also minimize damage, preserve and strengthen core values-for both individual nations and across the international community as a whole. The applied history elements here are:

\footnotetext{
16 M. MacMillan, The Uses and Abuses of History (Toronto: Penguin Canada, 20o8); cited in Colvin and Winfree, "Applied History, Applied Economics, and Economic History," 10.

17 B. de Graaf, L. Jensen, R. Knoeff, and C. Santing, "Historici moeten ook meedenken, juist nu", NRC/Handelsblad, 1 May 2020, https://www.nrc.nl/nieuws/2020/05/o1/historici -moeten-ook-meedenken-juist-nu-a3998484 (accessed 31 August 2020); extended and updated version: B. de Graaf, L. Jensen, R. Knoeff, and C. Santing, "Wicked problems en de noodzaak van een diepe blik", historici.nl, 13 May 2020, https://www.historici.nl/aan-de -slag-een-manifest-voor-applied-history/?type=bijdrage (accessed $3_{1}^{1}$ August 2020).
} 
understanding the nature of a current crisis and its transboundary management by paying attention to earlier crisis situations, their historical context, failure paths, their citizens' resources as well as attempting to compare these historical settings with an eye for differences and similarities in political attitudes and behavior.

To lay out an approach to respond to this question, we take the "focused comparison" approach in a diachronic and qualitative way to investigate three crisis situations involving the global community of states. These situations have several things in common: the pivot of international cooperation involved the Societas Europeana, the society of European states; some form of "platforms for deliberation"18 and modern diplomacy already existed (including so-called summits and multilateral conferences); and a specific type or set of pandemics ravaged the world. To draw comparisons over time, we need a more rigorous framework of fixed variables that we can apply to the given situations. That framework is taken from international public management theory, in particular from the flourishing literature on "transboundary crisis management" and cooperation (see below).

What now follows is first a brief incursion into the theory on transboundary crisis and cooperation, after which a framework for gauging "transboundary crisis management" will be applied to three situations of international crisis management in the distant and recent past.

\section{Theory: Transboundary Cooperation}

Why would states cooperate in times of crisis? ${ }^{19}$ Why would they not rather engage in rational free rider behavior - as many of them have done and still tend to do? It is a phenomenon that has captivated the attention of political scientists and international relations scholars since the ascent of that discipline in the 1920s. Why would states want to share or relinquish resources for the public good that will be used by others and hence will not be used to benefit their own polity or population? With respect to the example presented above: why would Angela Merkel be willing to give up so much of Germany's tax payer money (for which many indignant Germans have indeed blamed her)? Or, why was China willing to give Italy additional face masks and medical assistance in March and April 2020?

18 See: J. Mitzen, Power in Concert. The Nineteenth-Century Origins of Global Governance (Chicago: University of Chicago Press, 2013).

19 Blondin and Boin, "Cooperation in the Face of Transboundary Crisis," 198-199. 
As the literature has it, there are a variety of reasons to engage in international cooperation, as opposed to taking a lonely course or embarking on a course of conflict and war. First, cooperation may be the result of direct quid pro quo considerations-I'll help you, you help me. ${ }^{20}$ It could also be prompted as product of enforcement by great powers, in the same way the Warsaw Pact was the fruit of Soviet dominance over its satellites. Yet, cooperation may also come about through encouragement. Even though the Dutch were extremely unwilling to participate in the EU's recovery fund, and earned themselves membership among the "frugal four" (with Austria, Sweden, and Denmark), Merkel and Macron strongly encouraged the Netherlands to join the EU endeavor. Cooperation may, moreover, also be in everyone's natural interestdepending on the type of crisis. We could point to the EU's cooperation in the face of the "natural threat" that is emanating from Russia's land force and nearby borders; with Russia not being a member of the EU community, and perceived by its neighbors as a perennial menace. In the face of this overpowering threat, it is very much in the direct interest of the Baltic countries, for example, to work together with other EU countries in setting up a defense system. In line with this motivational position, cooperation could also be a default position; it can turn into an institutionalized habit, if the interaction is repeated, practiced enough, discussed abundantly, and enabled through administrative networks. ${ }^{21}$ Transnational cooperative arrangements such as the Benelux can hardly carry out some of their policy fields separately anymore because of the international frameworks in place. Even the Schengen Agreement, with all its faults, has morphed into such a fixed forum that it at least provides the rules and procedures to deal with conflict and contestation when they happen. The Schengen framework offers a platform to discuss, deliberate, and even renegotiate positions instead of allowing a complete breakdown of communication. Jennifer Mitzen calls these "deliberative forums," seemingly unimportant but yet so crucial administrative and oftentimes also effective ties. ${ }^{22}$

International cooperation seems reasonable but is not self-evident at all, as recent crises teach us. The 2015 refugee crisis did prompt a series of nationale Alleingänge, where East European countries pointblank refused to accept

$20 \quad$ R. Axelrod and R. Keohane, "Achieving Cooperation under Anarchy: Strategies and Institutions." In Neorealism and Neoliberalism: The Contemporary Debate, ed. D. Baldwin (New York: Columbia University Press, 1993), 85-115.

21 Blondin and Boin, "Cooperation in the Face of Transboundary Crisis," 202; M. Schulz, Normen und Praxis: Das Europäische Konzert der Grossmächte als Sicherheitsrat, 1815-1860 (Munich: De Gruyter Oldenbourg, 2009).

22 J. Mitzen, Power in Concert: The Nineteenth Century Origins of Global Governance (Chicago: University of Chicago Press, 2013). 
migrants and closed their borders, Schengen notwithstanding. Germany's government announced its acceptance of streams of migrants perhaps too early for its citizens to follow suit, and other countries, such as Italy and Greece, had to bear the whole brunt of the crisis. Another salient example: at the height of the Covid-19 crisis, the president of the United States announced that his country would pull out of the World Health Organization (wHO) and had already put much of its funding on hold. These two examples serve to illustrate the fact that international cooperation is not inevitable or a force of nature, but a product of international interaction, a means of "hard" and "soft" power. However, in an increasingly fragmented world, with international regimes for collective security (Intermediate Nuclear Arms Treaty with Russia), economy (WTO, NAFTA), and climate (Paris Agreement) vying to subsist and keep its organization from unravelling, this is a power hard to come by. ${ }^{23}$ In this chaotic situation, the Covid-19 crisis has only further highlighted and aggravated the chaos and the manifold frontlines splitting through existing fabrics of international cooperation.

These fissures in international cooperative arrangements beg the question therefore, how can the hard and soft power of international cooperation still thrive and play out in such situations of chaos and division? From Donald Blondin and Arjen Boin's theoretical discussion on collaborative crisis response, we derive five features or independent variables that determine the nature of the dependent variable (collective action or transboundary cooperation) and that can be projected on historical situations of transboundary crises, and highlight how and when transnational cooperation "works" and when it does not. ${ }^{24}$

First, effective transboundary crisis management very much depends on the type of crisis. With a common, looming, and imminent enemy/threat in place, cooperation comes easily. Where threat and enemy perceptions are polarized and politicized, where the crisis is not that acute but more creeping and less visible, cooperation will be a different challenge. Second, freedom of information is key: cooperation will not work in a situation where politicization and censorship dominate the stage; it only flourishes in situations where the information exchange works. The third point is in line with this: trust is equally important. Cooperation is based on the mobilization of existing networks of trust. With a heterogenous community of stakeholders/polarized, politicized communi-

23 J. Nye, "A Game of Three-Dimensional Chess with China." Beacon Journal, 13 June 2013, https://www.beaconjournal.com/article/20130613/OPINION/306139235 (accessed 31 August 2020).

24 Blondin and Boin, "Cooperation in the Face of Transboundary Crisis." 
ties, it is far more difficult. Fourth, according to Blondin and Boin, some type of enforcement or leverage should be in place. Can cooperation be enforced through institutionalized methods of sanction? Or can free riders/bail outers just get away with their behavior unpunished? And lastly, and very interestingly, group size matters: a limited body of actors works better together (as we all know from team assignments), than a large, heterogeneous bunch of proverbial frogs in a cart.

If this is the set of variables making up our research design, how will we test it? We will look closer into three instances of a perfect storm-a pandemic causing a deep transboundary crisis - and the responses to the crisis in terms of international cooperation: in the years 1812-1819, with the outbreak of plague typhoid fever in the wake of the last coalition wars and the demobilizing troops roaming through Europe, the Balkan and the Ottoman Empire (and thereafter, in the 1820s prompted by outbreaks of cholera); 1918-1919, with the unusually deadly pandemic of the Spanish Flu; and the current Covid-19 crisis of 2019 and ongoing. In the selection and description of cases, I depart somewhat from Steven J. Hoffman's periodization who in his excellent article sees the period between 1377 and 1851 as one characterized by unilateral health governance systems and only situates a nascent international dialogue and cooperation after 1851 , with the onset of international sanitary conferences. I agree with him that international health governance indeed follows a pattern of increasing multilateral norms, rules, and decision-making procedures. But this already started in 1815 and was overlayered in $1918 / 9$ by too much division and polarization within the international community. Existing international health bureaus were inhibited in their functioning because of the war and post-World War I divisions. Therefore, rather than viewing international cooperation in the realm of health as a single arc of increasing cooperation and success, focusing on these three situations $(1815,1918 / 9$, and 2020) also unveils ruptures and historical failure paths in cooperation. ${ }^{25}$

The five variables above are used to shape the focused comparison that follows.

25 S.J. Hoffman, "The Evolution, Etiology and Eventualities of the Global Health Security Regime." Health Policy and Planning 25 (6) (2010), 510-522. 


\section{Cholera and Plague in 1815: A Lot of Cooperation}

Napoleon unleashed the hounds of war over Europe and the wider world and brought home disaster, defeat, and disease in $1814 / 5$. Precisely because of the horror caused by the three-headed monster of war, revolution, and disease, the Concert of Europe decided to do things multilaterally. We could argue that 1815 marks the first instance of lasting multinational, collective action and international cooperation. ${ }^{26}$

The Final Act of Vienna and the Quadruple Alliance between Russia, Prussia, the Habsburg Empire, and the United Kingdom of 1815 laid the groundwork for a military, political, and even financial alliance that enforced European peace until 1854, and we could even say, if we do not take into account regional wars such as the Crimean War, until World War I. This cooperation was reinforced by the threat of pandemics and the mutual crisis management of such infectious diseases when they broke out. The great powers discussed matters of quarantine along the Habsburg border, checking the spread among the harbor cities along the Mediterranean littoral, joint inspections of ships from the Levant, and the creation of extra lazarettos and quarantine centers in cities such as Hamburg set up by private gifts and charity campaigns - a key pillar of citizens' resources. Within a couple of years this significant crisis was over. ${ }^{27}$

How can we explain this about-face so quickly after Napoleon's unilateral catastrophe?

\subsection{Type of Crisis}

The type of crisis as perceived by the state leaders of 1815 was all pervasive. It was acute and creeping, with its 5 million victims caused by the war and new victims succumbing in ongoing waves of infectious diseases coming in from the swarming armies of the alliance. In the "disease zone" of the Mediterranean, the years 1812-1819 saw one of the last major outbreaks of the plague in history, with approximately 300,000 deaths. ${ }^{28}$ The cumulative effect of deteriorated circum-

26 B. de Graaf, Fighting Terror after Napoleon: How Europe Became Secure after 1815 (Cambridge: Cambridge University Press, 2020).

27 See A. Robarts, "Nowhere to Run to, Nowhere to Hide? Society, State and Epidemic Diseases in the Early Nineteenth-Century Ottoman Balkans." In Plague and Contagion in the Islamic Mediterranean: New Histories of Disease in Ottoman Society, ed. Nükhet Varlik (Kalamazoo, MI: Arc Humanities Press, 2017), 221-242, 233-234; A. Chase-Levinson, "Early Nineteenth-Century Mediterranean Quarantine as a European system." In Quarantine: Local and Global Histories, ed. A. Bashford (London: Palgrave Macmillan, 2016), 35-53.

28 D. Panzac, La Peste dans l'Empire Ottoman, 1700-1850 (Leuven: Éditions Peeters, 1985); 
stances in economic and food circulation, climate change caused by a volcanic eruption in 1816, and famine and massive displacements forged the powers of the alliance together. The threat was clear enough: Revolution, Bonapartism, hunger, and "the potential rising up of the classes dangereuses" once more. To that end the great powers were willing to share information, work together, and accept each other's inspections and help. ${ }^{29}$

\subsection{Freedom of Information Exchange}

Even in times when censorship was virulent, diplomatic envoys created a multilateral network of intelligence and information, shared news on outbreaks of cholera or typhus. States used the existing allied ambassadorial and ministerial networks for discussing and translating information on troop displacements and demobilizations, as well as on the spread of diseases and worked them into central directives.

\subsection{Trust}

This worked between such strange bedfellows as absolutist Russia, liberal England, and militarized Prussia since the allied leaders, ministers, and experts had worked side by side, in horseback diplomacy, for the last twenty-five years, or at least the three years of the coalition wars since 1812, and had come to know each other very well. Habsburg, Ottoman, and Russian dignitaries worked together in creating cordons of checkpoints, issuing health bills and exchanging knowledge on lazarettos and quarantine practices. ${ }^{30}$

\subsection{Enforcement}

Together, the Quadruple Alliance (the Habsburg Empire, Russia, Prussia, and the UK) used their victorious power to enforce and encourage the second rank countries (Netherlands, Sweden, Portugal, Spain) to cooperate—among themselves but also with the Ottoman Empire and Persia.

D. Panzac, "Plague." In Encyclopedia of the Ottoman Empire, eds. G. Ágoston and B. Masters (New York: Infobase Publishing 2010), 462-463, 463.

29 See for cooperation with quarantine stations and lazarettos along the Mediterranean, E. de Lange, Menacing Tides: Security, Piracy and Empire in the Nineteenth-Century Mediterranean. PhD Dissertation, Utrecht University, 2020.

$30 \quad$ Chase-Levinson, "Early Nineteenth-Century Mediterranean Quarantine." See also G.F. Gensini, M.H.Yacoub, and A.A. Conti, "The Concept of Quarantine in History: From Plague to SARs." Journal of Infection 49 (4) (2004), 257-261. 


\subsection{Group Size}

The four met weekly in Paris; elsewhere, diplomats and envoys exchanged information equally frequently. In Toulon, Marseille, but also Istanbul and Vienna, the limited number of European representatives knew each other well and had to accept willy-nilly the guidance of the Quadruple Alliance those first postwar years.

In sum, seasoned diplomats paired experience with increasing collective knowledge on diseases and disease management, with great power enforcement of anti-infection measures. From 1815 onward, disease regulations and institutions were increasingly international and collectively organized. ${ }^{31}$ This had immediate effect on the mitigation of pandemics; with beginning illnesses being detected early enough, located and fixated. Knowledge, as rudimentary as it still was, was made available on how illnesses spread (water, air, insects). When in 1816 news of cholera reached Corfu, Ionian state authorities raised the alarm, published everything they knew about the disease in the Ionian Gazette and with the British colonial administration introduced therapeutic and surveillance information-gathering measures. In the years thereafter a Sanitary Committee was established that circulated and exchanged information with the Austro-Hungarian empire (which was ravaged by cholera as well), and with other states and authorities. ${ }^{32}$ And military resources were at hand to enforce the quarantine or lock-down.

This multilateral cooperation-resulting from both bottom up, local cooperation efforts, and higher up interactions on a diplomatic level-laid the foundation for more scientific cooperation and research on cholera and the plague, by using data based on recorded statistics in North African and Middle Eastern lazarettos-bringing medical experts to the insight that the plague was indeed a contagious disease and quarantine in ports was necessary to stop its spread. Information and knowledge was further translated into norms and regulations that were discussed and inaugurated in the sanitary conferences that were organized regularly from the second half of the nineteenth century onward. These conferences created platforms for standardization and crossborder cooperation on issues of health and sanitation, as Valeska Huber and Sylvia Chiffoleau have analyzed convincingly. ${ }^{33}$

31 M. Harrison, "Disease, Diplomacy and International Commerce: The Origins of International Sanitary Regulation in the Nineteenth Century." Journal of Global History 1 (2) (2006), 197-217.

32 S. Gekas, Xenocracy: State, Class and Colonialism in the Ionian Islands (New York: Berghahn Books, 2017), 275 .

33 V. Huber, "The Unification of the Globe by Disease? The International Sanitary Confer- 
Figure 2 shows a document from the joint European and Ottoman Conseil Supérieur de Sante de l'Empire Ottoman, composed of Ottoman officials and European scientists and medical doctors since the 183 os. It is signed by Ottoman officials, Bachi Effendi, the first physician to the Sultan. The other original signatures were six European medical doctors working in Vienna, St. Petersburg, Paris, and Constantinople. One of the signing physicians, Antoine Pezzoni, translated the results obtained in Constantinople in the international lazarettos into several international scientific texts on the importance of quarantine and about plague being a contagious disease. In 1847, he published a book, De la Contagionabilité de la peste fondée principalement sur les résultats obtenis par les quarantaines en Turquie, which was printed in Constantinople and became a standard tome for medical experts across the world. ${ }^{34}$

\section{$5 \quad$ Spanish Influenza in 1918/1919: Not Much Cooperation}

\subsection{Type of Crisis}

The Spanish flu was a completely different story. The crisis of the Spanish Influenza conflated with the last year and months of World War I. As in 1815, viruses were disseminated and brought to Europe via the trail of mobilizing and demobilizing soldiers during and right after a global war.

This time, Europe was divided, Russia was in turmoil after the revolution, the Ottoman Empire was dissolving, and the United States withdrew into isolationism after its initial role as power broker. Contrary to 1815 , no effective allied council or ambassadorial conference arose in unified form to discuss the pandemic. The question of war guilt, the German revolution, and the role of the United States divided the wartime alliance, with the new Soviet Union mired in its own domestic troubles, and the Ottoman Empire carved up in neocolonial protectorates. No central directives, international quarantine regimes or lazarettos were set up. It was every country, every army on its own. The crisis came moreover in three, distinct peaks, rather than in longer lasting waves and

ences on Cholera, 1851-1894." The Historical Journal 49 (2) (2006), 453-476; S. Chiffoleau, Genèse de la Santé publique internationale: De la peste d'Orient à l'oms (Beyrouth: Institut Français du Proche-Orient / Presses Universitaires de Rennes, 2012).

Conseil Supérieur de Sante de l'Empire Ottoman, "Conseil Superieur de Santé de l Empire Ottoman. Messieurs. Dans la séance du 13 Septembre tenue par l academie des Sciences a Paris, Mr. le Dr. Aubert lut in Mémoire." (Constantinople, January 7, February 5 and April 2, 1842), https://www.iberlibro.com/Conseil-Superieur-Sant\%C $3 \% A g-1 \% \mathrm{C}_{2} \% 92$ Empire-Ott oman-Messieurs/30176350649/bd (accessed 31 August 2020). 


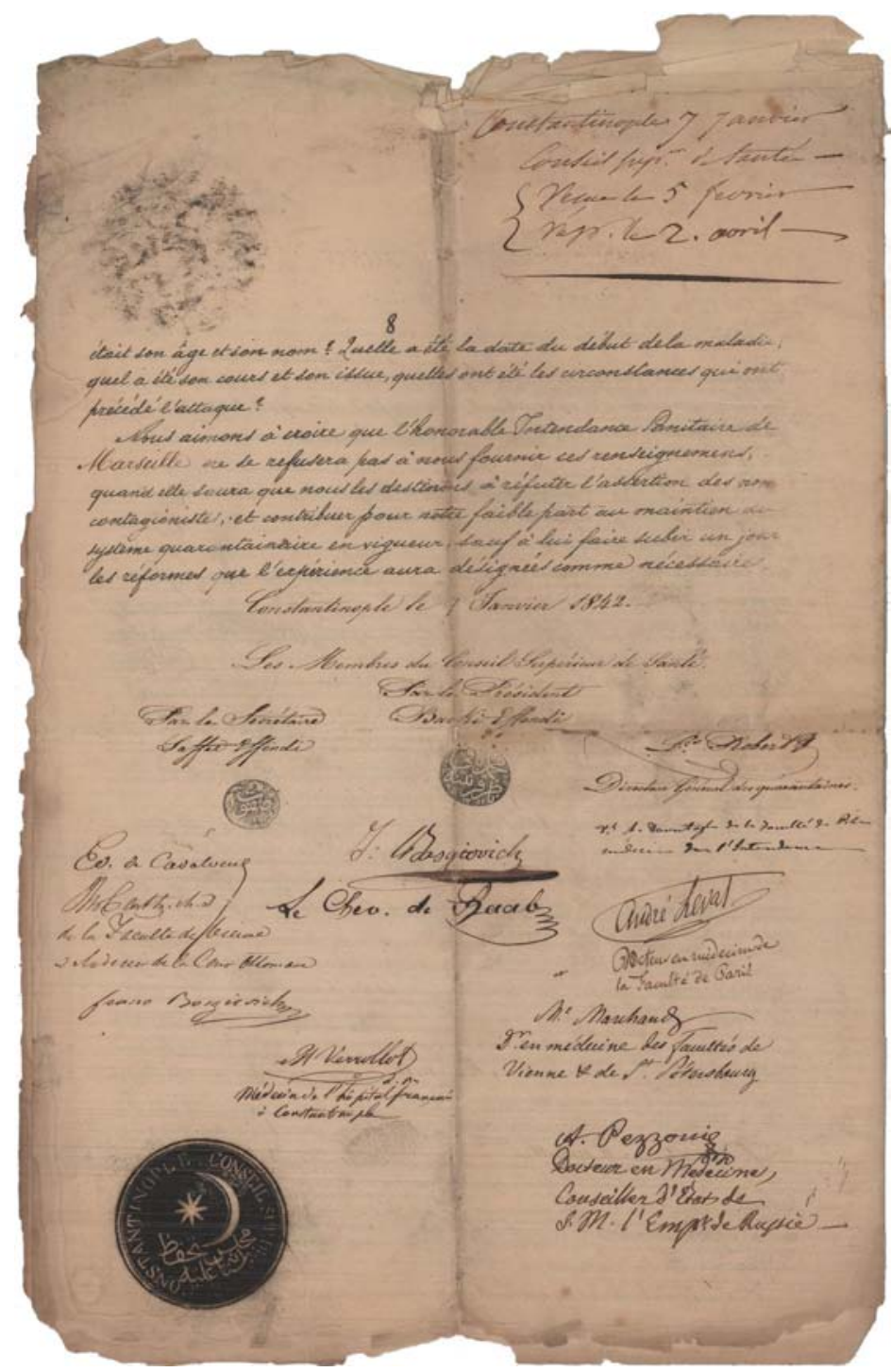

FIgure 2 Conseil Supérieur de Sante de l'Empire Ottoman, Public announcement on anti-plague measures, Constantinople, January 7 (additional manuscript dated February 5 and April 2), 1842. Private collection, Antiquariat Dasa Pahor SOURCE: CONSEIL SUPÉRIEUR DE SANTE DE L'EMPIRE OTTOMAN, PUBLIC ANNOUNCEMENT ON ANTI-PLAGUE MEASURES 1842. USED WITH PERMISSION OF ANTIQUARIAT DASA PAHOR 
crescents. This meant that no general, overarching, unifying threat and interest perception_- "fighting the flu together" — could arise. ${ }^{35}$

\subsection{Information Exchange}

The lack of cooperation started with the first obstacle: information and intelligence about the type of illness and its patient zero or point of outbreak.

In principle, an International Bureau for Public Hygiene had been set up in Paris in 1907 as a centralized storage agency for intelligence on diseases and as monitoring agency for corresponding measures. Doctors in Europe were obliged to report diseases to their local, regional authorities. They had to report highly infectious, dangerous diseases to the Bureau, such as smallpox, tuberculosis, and cholera. But for influenza, there was not yet a reporting obligation. And most countries, as stated before, had imposed a curfew and censored the press. $^{36}$

When the disease was diagnosed in Spain in May 1918 and reported in the newspapers, it was already well under way, it had been roaming through the United States since February, and in France since March. But hardly anyone was aware of this, since in these countries, news on the influenza was subject to heavy censorship in order not to undermine the troops' morale. French army doctors ominously and obscurely referred to the maladie onze (eleventh illness). Therefore, the Spanish inspector general of health Martin Salazar, had to report to the Royal Academy of Medical Sciences in Madrid that he had not found information or sightings of a similar disease elsewhere in Europe. When newspapers wrote about this infectant, which had made two-thirds of the Madrilene population ill within a few days, French, British, and American papers began to defame the illness as the Spanish Influenza, blaming neutral Spain as the cause. ${ }^{37}$

Only Australia acted in time, since it had read about the influenza pandemic in Europe in the summer of 1918 and reacted quickly to impose a maritime quarantine on 18 October 1918 (New Zealand did not). Only the third influenza wave in 1919 would hit the country (since it lifted the quarantine too prematurely), but that wave was not as devastating as the 1918 ones.

35 See for a masterful narrative on the Spanish Flu, L. Linney, Pale Rider: The Spanish Flu of 1918 and How It Changed the World (London: Jonathan Cape, 2017); or a more succinct text, F. Snowden, Epidemics and Society: From the Black Death to the Present (New Haven, CT: Yale University Press, 2019), 84-85.

36 P. Céline, "L'Europe et les organisations sanitaires internationales: Enjeux régionaux et mondialisation, des années 1900 aux années 1920", Les cahiers Irice 1 (9) (2012), 47-6o.

See Spinney, Pale Rider, chapter 5 . 


\subsection{Trust/Politicization of the Illness}

Wartime polarization and military frontlines spilled over into the political realm. Politicizing the illness started immediately, as exemplified in the way the disease was named: in Senegal, it was named the "Brasilian flu"; in Brazil, the "German flu." Denmark called it the "southern disease," whereas it was the "bolshevist plague" in Poland, and for Spain, it was the "wrath of God." In the eyes of the clergy and the conservative elites, the infection was attributed to the loosening of sexual liberties in modern times. ${ }^{38}$

\subsection{Enforcement}

Given the fragmented and chaotic sortie de guerre, no unified, effective allied council emerged out of the ashes of the world war as in 1815. US President Woodrow Wilson was very likely also affected by the flu and political opposition at home, and was powerless to give the League of Nation the necessary teeth to enforce collective military, let alone political or health, cooperation. He had to carry out negotiations in April 1919 while lying in bed. Moreover, the Office International d'Hygiène Publique and the League of Red Cross Societies clashed over responsibilities, whereas MP Neville Chamberlain, who dominated League negotiations in 1919 was strongly opposed to financing the League's epidemic commission and funneling money to Poland, which had suffered heavily from a typhus epidemic at that time. He was only willing to give 50,000 pounds on the condition that the United States, France, Holland, and Spain contribute the same amount (which they would not). A first International Epidemic Commission was set up, but due to Polish-Lithuanian aggression could not impose a cordon sanitaire in Eastern Europe. According to the British Treasury:

the doctrine that the British government should tax the British taxpayer for the purpose of combating typhus in Poland on the grounds that it would be open to HMG to look for assistance from the Polish taxpayers (among others) for assistance in meeting the cost of an outbreak of typhus in IUK should such occur appears to their Lordships a manifest absurdity. 39

38 See Spinney, Pale Rider, chapter 5, 7 .

39 P. Weindling, ed., International Health Organisations and Movements, 1918-1939 (Cambridge: Cambridge University Press, 1995), 45. 


\subsection{Group Size}

In short, the group size was too large, the nations too divided, no single superpower or two, three, or four superpowers wanted to work together; Britain was too frugal, the rest too careless.

In sum, it took another war, and another series of pandemics (among them the Asian Influenza of 1957 and the Hong Kong Influenza of 1968), before an international network for influenza surveillance was created..$^{40}$ The wHo expanded its network of influenza administration ever since, with currently 110 national influenza centers operating in 82 countries, and four wHo Collaborating Centres for Reference and Research on Influenza located in Atlanta, USA; London, UK; Melbourne, Australia; and Tokyo, Japan. ${ }^{41}$

Against the background of these two historical situations of pandemics and the successes and failures of engaging in transboundary cooperation, the Covid19 crisis seems so far a less lethal pulmonal influenza pandemic. Still, it is the first pandemic crisis in history where the development of the pandemic in its epidemiological and medical statistics can be followed in real time. ${ }^{42}$ It is also the pandemic that can be considered to have one of the most pervasive economic and democratic effects, in the way lockdown measures impact the global economy and discussions of these statistics, official analyses and regulations unrolls globally and online on a $24 / 7$ basis. Millions of ordinary citizens are affected in their daily life, not necessarily through medical impairments, but far more through the socio-economic effects of safety and sanitary regulations. Moreover, these citizens now present themselves as experts on all virological and epidemiological matters imaginable. Remarkably, it is also the first time in history that global and national lockdown measures have been deployed across the scope of the public domain crisis. How are the variables aligned

$40 \quad$ E.D. Kilbourne, "Influenza Pandemics of the 2oth Century." Emerging Infectious Diseases 12 (1) (2006), 9-14.

41 World Health Organization, "wHo Collaborating Centres for Influenza and their Terms of Reference," World Health Organization, https://www.who.int/influenza/gisrs_laboratory/ collaborating_centres/list/en/ (accessed 31 August 2020).

42 Leopoldina Nationale Akademie der Wissenschaften, Dritte Ad-hoc-Stellungnahme: Coronavirus-Pandemie—Die Krise nachhaltig überwinden (Halle, 13 April 2020), 7. 
today? What can we say about the type of crisis, exchange of information, trust, enforcement, group size — and what kind of scenarios could we expect, based on our historical imaginations?

\subsection{Type of Crisis}

First of all, this crisis is still ongoing (with a possible second wave under way in July 2020), which makes it quite hazardous to assess the situation historically. But it is safe to state that this pandemic it is not only an acute or flash crisis, but also a creeping one. It lays siege to a society, as medical historian Frank Snowden has aptly put it. And it is not just a health and medical crisis. Snowden deems it the first truly globalized disease, caused by the great population explosion of the last decades (with currently 8 billion people on the planet) and rapacious industrialization. According to Snowden, the Chicago/Friedman view on economic growth ad infinitum is eroding the planet's finite resources (such as palm oil), thereby inducing the rise of more zoonotic viruses. At the same time, the crisis is also a product of a greedy attitude toward environment and deforestation, made worse by populations and peoples and commodities constantly on the move, from one urbanized center to another. ${ }^{43}$

The question is whether this health crisis will generate overarching, integrative threat and interest perceptions. The Covid-19 crisis is transforming into a hybrid, political, contested crisis as we speak: not just health, but global trade and economy have started to deteriorate. The outbreak has prompted widespread confirmation bias: ${ }^{44}$ one party sees climate change as causative agent and demands investments in sustainability; the other sees poverty as a major driver, on a global level, between the Global North and the Global South, and within countries, with third world countries suffering since they will not be able to practice social distancing or pay for expensive treatments and recovery medicines. The third party, conversely, sees Covid-19 as further proof of China's nefarious role and policies. In short, Covid-19 has turned, within the four months (as of this writing) since its outbreak, into a meta-crisis of global

43 "Online Lecture by Frank Snowden, Hosted by the European Council on Foreign Relations," 7 May 2020. For the podcast that was made out of it, see https://www.ecfr.eu/ podcasts/episode/covid_19_as_the_first_pandemic_of_globalisation (accessed ${ }^{1}$ August 2020); S. Gonzalez, "Historian Frank Snowden: May We Be 'Forever Changed' by Coronavirus." Yale News, 8 April 2008, https://news.yale.edu/2020/o4/o8/historian-frank-snow den-may-we-be-forever-changed-coronavirus (accessed 31 August 2020).

44 R.R. Britt, "Why People Won't Change Their Minds on Covid-19." Luminate, 1 June 2020, https://medium.com/luminate/why-people-wont-change-their-minds-on-covid-19-efcac e6ae93e (accessed 31 August 2020). 
scope; with every state trying to assert its defining power over what exactly the main threat or interest is that needs defending.

\subsection{Exchange of Information}

Things are not helped by the paradox of a huge lack of information: on the origins (China? Bats? Pangolins?), on the type of illness (pulmonal, intestine), on the modes and vectors of contagion and dissemination (aerosols, the elderly). In 1815 , the global community experienced one of the last major plague outbreaks in the history of humankind; at that time, the plague had already morphed into a feared but quite familiar and well-known enemy. Corona viruses, conversely, are still very alien, unpredictable, and unknown in their effects and impact. At the same time, the abundance of information is blindsiding societies in designing a way forward. Citizens with internet access have been digitally schooling themselves over the last past months into becoming epidemiologists, with the internet erupting with conspiracies on the "true agents" of pandemics. This historical failure path in arriving at a joint body of knowledge and understanding is reminiscent of the situation in 1918/9 when the Spanish Flu was also politicized and surrounded by — what we would now call—-fake news' and conspiracies from the start.

\subsection{Trust}

The previous observation also points to the lack of trust among the global community of states. The global war on terror, the rise of populism, the migrant crises, and the unraveling of US leadership in international organizations over the last two decades have created a fragmented world order. Trust in governments is the main commodity of successful public and social health measures: from lockdowns to cordons sanitaires, testing and tracing - in open societies usually in the Western states, governments depend on their citizens' willingness to cooperate. As in 1918, pockets of resistance are mounting. Leaders flouting the rules, from Brazil to the United States and the UK does not help either.

\subsection{Politicization}

This plays into politicization. It is amazing how high the level of support for most governments is and how acquiescent and orderly the masses have behaved. But exiting the lockdown will still be a bumpy road, or worse, with politicization looming large.

\subsection{Enforcement}

Tragically, in the 199os, calls for more international and collective action to enhance preparedness were there, with the avian flu spreading in 1997. Interna- 
tional associations of virologists announced that pulmonary flu diseases were the new global infectious disease. SARS in 2002/3 was a prequel to Covid-19. US medical expert Anthony Fauci testified about this before Congress. ${ }^{45}$ Comparisons were made with the level of preparedness in the Caribbean, a place coexisting with tornados. Mutatis mutandis, preparedness regarding epidemics is essential for every state and society with high levels of vulnerability to the spread of diseases (be it through population density or openness to global streams of trade and transport). Funds were set up and utilized during the SARS crisis, but the flow of money has dried up since then. Instead of funding the WHO again, the US president announced a complete break from the organization, leaving individual nations, or groups of nations to deal with the pandemic alone. Yet, as wHo president Tedros Ghebreyesus noted, microbes do not respect borders. And pandemics will be endemic to our unregulated global societies. ${ }^{46}$

\subsection{Group Size}

It is quite likely that the group size was too big or the number of superpowers willing to broker international crisis management together was too small, and made even smaller by being divided against each other.

In sum, negative associations and failure paths show how to inhibit effective international cooperation: stigmatization, politicization, and polarization regarding the virus as such or the regulations introduced (masks) remind us more of 1918/9 then of 1815 . Free circulation of conspiracy theories and hoax therapies seem irrational ploys that detract from real causes and mechanisms of contagion. In many countries, leaders are bowing to populist outcries rather than engaging in solid transboundary cooperation. At the same time, and again similar to 1918 , some countries are undercutting the free flow of information on

45 See, for example, National Institute of Health, "Testimony before the Permanent Subcommittee on Investigations Committee on Governmental Affairs United States Senate. NIH's Response to the Global Outbreak of Severe Acute Respiratory Syndrome (sArs). Statement of Anthony S. Fauci, M.D. Director National Institute of Allergy and Infectious Diseases National Institutes of Health Department of Health and Human Services." (Washington: 21 May 2003), https://www.hsgac.senate.gov/imo/media/doc/o52103fauci .pdf (accessed 31 August 2020).

46 See World Health Organization, "wHo Director-General Opening Remarks at the Member State Briefing on the CoviD-19 Pandemic Evaluation-9 July 2020." World Health Organization, 9 July 2020, https://www.who.int/dg/speeches/detail/who-director-gener al-opening-remarks-at-the-member-state-briefing-on-the-covid-19-pandemic-evaluation ---9-july-202O (accessed 31 August 202O). 
origins and initial spread of the pandemic. Journalists and scientists in China and medics and surgeons in Russia are censored or outright neutralized or eliminated.

From our applied history perspective, new elements stand out in the way the global community is managing (or failing to manage) this pandemic metacrisis. New to 2020 is the all-pervasive role of pharmaceutical giants in the trajectory toward a vaccine. It seems that some corporations are promoting untested or even dangerous prophylactics for commercial reasons, and thereby inhibit the development of vaccines. ${ }^{47}$ This also reveals another deficit that belongs to this day and age of widespread expertise and knowledge, but of exaggerated commercialization of that same knowledge: a market failure. Then, "what firm will invest millions developing a drug for a nonexistent pandemic market?" Here, governments have evacuated the public policy space and abandoned it to market forces that lack the interest and foresight of investing in such pandemic medicines. ${ }^{48}$

Another novelty to the historic setting of pandemics in 2020 points not to a lack of information, but to the flooding of the public space with information. Citizens broadcasting personal programming congest the public channels of communication and information with 'fake news' and more uncertainty.

Yet, some variables also point in more hopeful directions, predominantly with respect to group size, leadership, and "citizens resources" and/or "expert resources." Smaller groups of nations have emerged-in South-East Asia (ASEAN), South Africa/Nigeria, and Europe-engaging or mobilizing existing and new alliances and bureaucracies to help administer the crisis together. At the same time, a new type of leadership seems to stand out: in Taiwan, New Zealand, and Australia female leaders have stood up, and decidedly renounced further polarizations, while managing to create networks of trust and solidarity. Within the EU, Angela Merkel's Germany has taken over the rotating EU presidency and has already demonstrated how the European Union will "take a leading role and engage more financially" (see above).

Moreover, as in 1815 , international scientists and experts break through national and disciplinary barriers. In 2020, they share their findings without waiting for peer reviews and publication permissions, and work together via universities, or regional WHO offices and NGOS. Similar to the rise of the sanitary movement in the nineteenth century, scientists are again pushing

\footnotetext{
47 J. Pannu, "Running Ahead of Pandemics: Achieving In-Advance Antiviral Drugs." Special Edition Policy Brief (Mercatus Center and George Mason University, March 31, 2020), https://ssrn.com/abstract=3570737 (accessed 31 August 2020). 
their leaders and governments toward more cooperation, solidarity, and transparency. In Australia, modeling scientist Peter Doherty emphasized that the WHO is "central to the global fight against COVID-19." Richard Horton, the editor of the Britain-based Lancet Medical Journal, combined its criticism of Trump's handling of the crisis with support for more transboundary crisis management: "We give our $100 \%$ support to the World Health Organization at this time of crisis." 49

\section{A Last Caveat: Dangers of International Cooperation and Crisis Management}

One caveat needs to be formulated: namely, the normative context of transboundary cooperation. Who, then, is to profit from collective action? In 1815, imperial elites profited from the cordon sanitaires to the detriment of nonEuropean, colonial outsiders. The elites moreover turned against alleged aliens and non-residents. Indeed, international cooperation has turned against the impoverished of the earth numerous times in history: against the underdogs, as in Latin America in 1904; in Brazil and other countries, conservative regimes demolished hundreds of houses and streets, to make way for the splendor of municipal projects such as the Avenida Rio Branca. A "scientific dictatorship" permanently undermined the rights of the poor and the population. In the 193os, germ theory circulated internationally and the fear of the classes dangereuses went hand in glove with enhanced governmental and international control: eugenetics and racial biopolitics entered the realm of international crisis management and information exchange. Given these very dark historical failure paths, it is imperative to raise the issue of oversight in transboundary cooperation. International cooperation and collective security are executed without accountability to international parliaments or hearings. There is hardly an instance of international voting against intrusive directives dictating body politics - for example, when new regulations on airports are considered.

Given our framework of five variables, it would be interesting to add a sixth variable to that package, the level of oversight, or accountability-with the hypothesis providing such instruments of oversight and accountability could "improve" the nature of transboundary cooperation, and make it more just and

49 K. Adam, "Trump's Exit from who Met with Dismay." Washington Post, 30 May 2020, https:/www.washingtonpost.com/world/trump-world-health-organization-criticism/2o 2o/05/3o/a9650984-a26b-11ea-beo6-af5514eeo385_story.html (accessed 31 August 2020). 
equitable. ${ }^{50}$ Historical evidence seems to underpin this hypothesis, if we follow Samuel Cohn in his findings on how widespread and long-lasting rebellions were prompted not by the confrontation with plague and pandemics per se, but by anger and frustration over the way elites handled the crisis unevenly and unjustly. ${ }^{51}$ Far more research needs to be done in this direction for the twentieth century. Did measures that were perceived as "unfair" or unjust prompt similar waves of protest and rebellion when, for example, influenza, SARs, or the AIDS epidemics were treated?

\section{$8 \quad$ Conclusion}

From the perspective of applied history, the trajectory of transboundary crisis management in times of pandemics is a highly rich and fascinating one. We have seen how specific conditions had a significant impact on how the international community of states handled a crisis. Interestingly, the size of the group was and is of key importance; smaller groups, with leaders who are seasoned in summitry and negotiations (and preferably know and trust each other) operate far more effectively than large scale organizations. In other words, the Quadruple Alliance of 1815 seemed more effective than the WHO today in managing international cooperation.

Also conducive to transboundary cooperation is the ability to limit and overcome the level of politization and polarization that always follows a pandemic in its wake. Here, leadership is of utmost importance and would demand more time and space to investigate from a historical perspective. It seems that female leadership - a novel phenomenon in historical pandemic crisis situationshas had a beneficial effect both on cooperation and on mitigating the fall out of politicization in $2020 .{ }^{52}$

The role of citizen's resources has been under-researched as well. How has the increasing centralization and international institutionalization of crisis management and sanitary regulations impacted the level of citizen's involvement? Have NGO s been able to take over from the charitable and religious orga-

50 See also on the divide between rich and poorer countries, M.R. Snyder and S.J. Ravi, "1818, 1918, 2018: Two Centuries of Pandemics." Health Security 16 (6) (2018), 410-415.

51 S.K. Cohn, Jr., Lust for Liberty: The Politics of Social Revolt in Medieval Europe, 1200-1425 (Cambridge, MA: Harvard University Press, 2006), 208.

52 A. Taub, "Why Are Women-Led Nations Doing Better with Covid-19." New York Times, 15 May 2020, https://www.nytimes.com/2020/05/15/world/coronavirus-women-leaders .html (accessed 31 August 2020). 
nizations of the early modern era? Or should we consider the role of experts and their transnational networks as the way citizens' resources have transformed over the last two centuries?

Another element that we have only touched upon is the entanglement between welfare states and the market. For effective, equitable, and inclusive international cooperation in the realm of health and sanitation, it seems pharmaceutical firms (that novelty of the late twentieth and early twenty-first centuries) should be kept on a leash; since with their monopolies and pushing of specific therapies, they are at the same time revealing a market failure by failing to invest in the production of timely vaccines and opening up the chasms between wealthy and poor countries in the world of health and medicine.

\section{Acknowledgments}

The author wishes to thank Arjen Boin, Annelotte Janse, Erik de Lange, Ozan Ozavci, Joep Schenk and Carla Spiegel for their feedback and critical comments, Ilana Brown for the editing, and Harm Kaal and Jelle van Lottum, the editors, for their encouragement in submitting this paper. I would also like to express thanks for the inspiration that I drew (and still am drawing) from the cooperation with Lotte Jensen, Rina Knoeff and Catrien Santing on the Applied History Manifesto. 